\title{
RHINOCEROS 5 + VRAY AS A TOOL FOR THE EVALUATION OF CONDITIONS IN BIC ENVIRONMENTS: THE CASES OF THE ATARAZANAS, THE CONVENT OF SAN AGUSTIN AND THE PLAZA NUEVA IN SEVILLE
}

\author{
J. Navarro-de Pablos ${ }^{1 *}$, C. Mosquera-Pérez ${ }^{2}$, D. Navas-Carrillo ${ }^{1}$, B. Del Espino Hidalgo ${ }^{3}$, M. T. Pérez Cano ${ }^{1}$
}

\author{
${ }^{1}$ University of Seville, Higher Technical School of Architecture. Department of Urban and Territorial Planning. Research Group \\ "Heritage and Urban Territorial Development in Andalusia”(HUM-700), 41012 Seville, Spain - fnavarro@us.es, dnavas@us.es, \\ tpcano@us.es \\ ${ }^{2}$ University of Seville, Higher Technical School of Architecture. Department of Architectural History, Theory and Composition. \\ Research Group "Heritage and Urban Territorial Development in Andalusia” (HUM-700), 41012 Seville, Spain - cmosquera@us.es \\ ${ }^{3}$ Andalusian Institute of Historical Heritage (IAPH). Regional Government of Andalusia. Research Group "Heritage and Urban \\ Territorial Development in Andalusia” (HUM-700), 41092 Seville, Spain - blanca.espino@juntadeandalucia.es
}

KEY WORDS: Applied graphic innovation; Teaching material based on infographics; Dissemination in urban legislation; Asset of Cultural Interest; Historical complex of Seville; Urban parameters in BIC environments

\begin{abstract}
:
This contribution aims to deepen the formulas for the application of 3D modelling tools in their application to the protection of heritage in the Spanish legislative framework: Although they emerge as instruments for their eminently industrial application, new architecture or infographics, the Rhinoceros software, together with the Vray rendering engine, constitute a tandem that has proved to be very useful for determining the degrees of impact (heights, perspectives, buildability, occupation and other urban parameters) in real estate environments declared to be of "Cultural Interest" (from now on referred to as "BIC" - or Asset of Cultural Interest), according to the regional legislation of Andalusia. In addition to the didactic character of the results, which allows their dissemination as teaching material applied in the Degree in Fundamentals of Architecture of the University of Seville, the three case studies presented facilitate the reading of the environment affected by the specific regulations, as well as the technical determination of the visual pollution that the surrounding buildings cause in the building itself. The three case studies include buildings declared "BIC", which are in very different situations of conservation and use, all in the city of Seville, in the south of Spain: while the City Council, which presides over the most important square in the city, is the paradigmatic model of a dynamic and inhabited square, the Atarazanas (former shipyard factory) are in a good state of conservation, but without defined use. The last case, the extinct convent of San Agustin, in addition to not being used, is in a state of ascending deterioration, since a large part of its construction has disappeared thanks to real estate expansion and the absence of legislative protection of the heritage.
\end{abstract}

\section{INTRODUCTION}

1.1 Objectives and methodology: definition of BIC environments and their analysis through infographics.

The protection and conservation of the "surrounding space" of monuments and other types of immovable property is an aspect of the protection widely recognized and considered in the legislation on Historical Heritage in Spain. This aspect is introduced as a guarantee of protection not only of the property itself, but also of the added landscape values that arise from the relationship between the architectural object or public space and the rest of the contour. The appearance of "environments" in legislation began to be recognised in the Royal Decree-Law of 9 August 1926 relating to the National Archaeological and Artistic Treasure (Ruiz, 1995) and developed by the competent administration. In order to develop and improve the application of this aspect, and after the enactment of Law 16/1985 of 25 June, a legal figure and a tutelary-objective concept were introduced which tried to specify the spatial area occupied by the undetermined "surrounding space". Similarly, it collects the normative dispositions established for its ordering.
The latest legislative update, approved by the regional government (Law 14/2007), advances the methods of delimitation of environments, as well as incorporates issues of visual and perceptual pollution (De-Carvajal, 2008). With this inclusion, it becomes evident the need to study the possible visual affections in $3 \mathrm{D}$, surpassing the traditional vision in plant and section.

The main reason for the application of 3D modelling as a support instrument to assess the risks and threats surrounding built heritage is, in fact, the absence so far of $3 \mathrm{D}$ graphic information in technical legislative documents (Navas et. al., 2018). It is also a tool of special interest in a context where the protection of heritage has entered the judicial sphere as a reason for dispute between administrations. Since people who do not belong to the field of specialisation of architecture must intercede, it is necessary to find suitable expressive ways to make the complex heritage reality of the historic city understandable (Fritsch et. al., 2018). The methodology followed is determined by the characteristics of the software, having first carried out a 2D planimetry with the ACAD drawing tools. Subsequently, the export of these files to Rhinoceros allows a 3D survey to be carried out contrasting the current urban planning, the perspectives generated through the Google and Bing maps and the organoleptic review itself. Finally, the provision of basic textures allows its use as didactic and understandable material, as 
well as facilitating its inclusion in technical documents that must be evaluated by professionals outside the architecture and reading of traditional planimetries. This last phase was replaced in the case of the Shipyards by a postproduction in Adobe Photoshop, after generating an axonometric model. This sequence is preceded by the compilation of the relevant historical documentation, collected mainly from primary sources and insitu recognitions. The extensive joint work of the departments of Urban Planning and Territorial Planning and Architectural History, Theory and Composition of the Higher Technical School of Architecture of Seville, developed over more than twenty years in the research group HUM-700 "Heritage and UrbanTerritorial Development in Andalusia" allows for a team of researchers and support staff of the highest level.

For the three case studies addressed, three different internal commissions were set up to deal with documentation and logistics tasks. The results demonstrate its consolidation as a useful tool when assessing the possible effects of buildings on the environment, with the added possibility of generating human scale perspectives by introducing cameras inside the buildings under study. Its usefulness is demonstrated by the use of graphic documentation in several technical reports that have managed to unblock long disputes between heritage organisations and various public developers. In the previous lines, the results have demonstrated the suitability of the use of 3D graphic expression systems to deal efficiently with the extensive and diverse amount of information that characterizes heritage research on an urban scale. From the study of historical cartography, its evolution has been interpreted. The detailed recording of urban information has allowed us to propose improvements in planning with regard to the conservation of the urban environment, especially with regard to its historic centres. Among them, the impact that the height of new buildings can have on the perception of monuments and on the conservation of a given historic urban environment has been highlighted. Being research in development, the use of these 3D softwares will allow not only to record the data resulting from the quantitative and qualitative analysis carried out on the environment of isolated real estate, but also the analysis and graphical representation at multiple scales using the third dimension to facilitate a crossanalysis between all the information.

The main advantage of its use is its ability to be applied at different scales: from the general recognition of a city to the analysis of singular buildings, the integral vision offered by the system allows it to respond to two fundamental objectives. Firstly, to arrive at a metric-scientific definition of the city's spatial parameters and, secondly, to facilitate the dissemination of urban heritage thanks to its graphic potential (Fassi et. al., 2016). Other transversal objectives of its application are the improvement of the knowledge of urban evolution or its use as didactic material. As a last point, it is precisely the double informative and scientific character of the generated material that allows its application not only in the technical field, but also in teaching. The teaching tasks developed by the aforementioned university research group allow the dissemination of the tool to be assumed by the students of the Degree in Fundamentals of Architecture from the university training itself. This has been demonstrated in the practices developed with students in the subjects of "Urban Heritage and Planning", "Urbanism I", or "Architectural History, Theory and Composition" of the university degree.

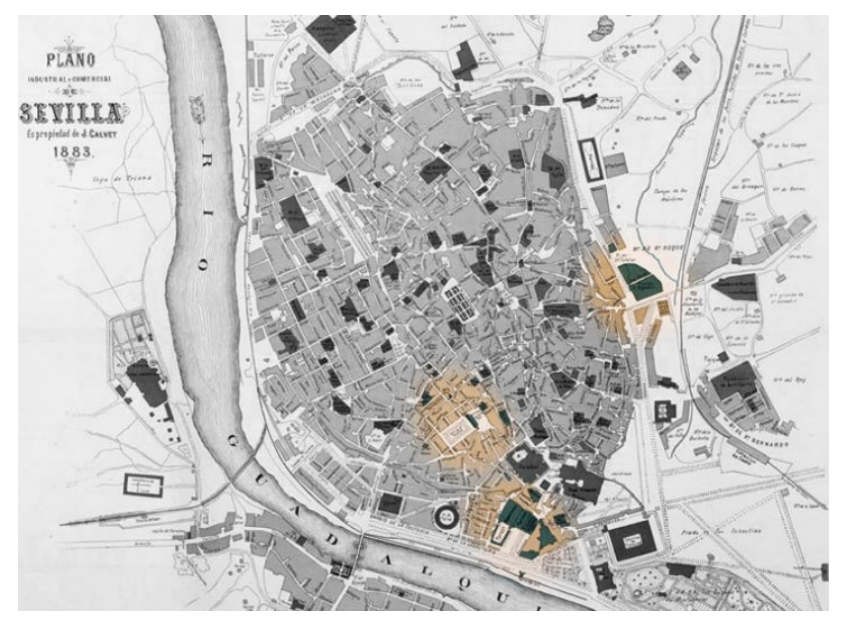

Figure 1. Map of the city of Seville in 1883, property of J.

Calvet. The three cases of studies are indicated: the convent of

San Agustin in the upper right part, the Plaza Nueva in the center and the Royal Shipyards in the lower part. (Consulted in the Virtual Exhibition of the National Library of Spain, 2019)

\section{STUDY CASES: THREE SCALES, A SINGLE TOOL}

\subsection{An interscalar tool}

The three case studies in which this methodology has been applied arise from three different circumstances: firstly, the surroundings of Seville's Plaza Nueva were part of a research project that sought to find the heritage transformations suffered in the surroundings since its construction. Secondly, the Royal Shipyards are part of the heritage justification to unblock the rehabilitation project in cultural headquarters, entrusted to the research group HUM-700. Finally, the case of St. Augustine has also been developed as part of a technical document (Special Plan of San Agustin) that needed an understandable graphic material for public reading.

This trident of cases means the confirmation that the methodology has been successfully applied since it serves for three different scales: Plaza Nueva (size L), Las Atarazanas (size M) and the convent of San Agustin (size S).

\subsection{The 2D planimetry construction process}

Despite the trend detected in recent years towards an assisted drawing model based on BIM technology in the field of architecture (Pérez et. al., 2017), two-dimensional drawing based on $\mathrm{CAD}$ continues to be the most widespread tool in the professional and research field in Spain (Verdu et. al., 2015). The field of study of this article also contains an eminently patrimonial and urban legislation component, an aspect that brings together values and elements that do not yet seem to have been taken into account by BIM technology. 


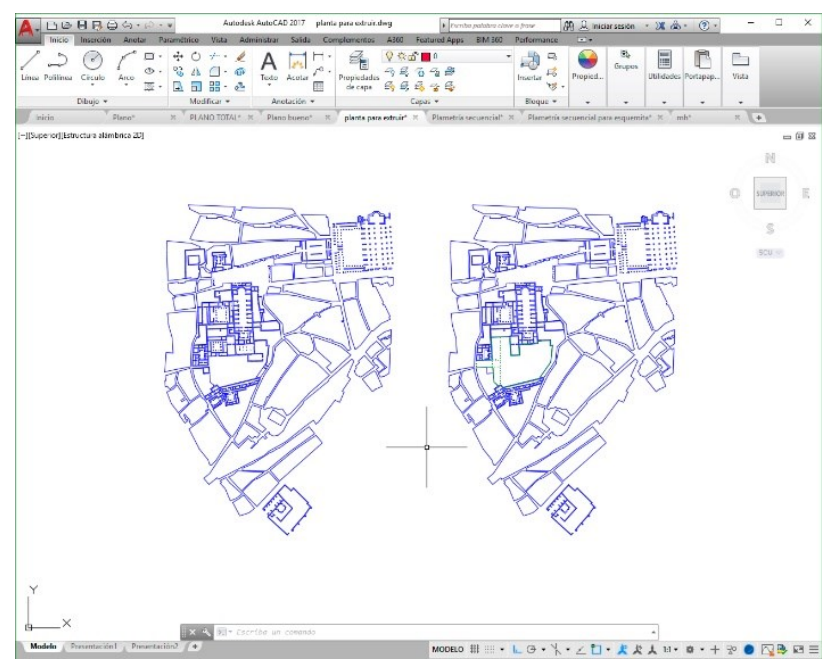

Figure 2. Screenshot of the 2D drawings made for the Plaza Nueva case. To the left, the planimetry of the old convent of San Francisco. To the right, the unrealised project by Cayetano Vélez. (The authors, 2017)

In this way, the studies on the environments of the buildings and public spaces that are the object of study have started from a CAD base, with its corresponding hierarchy of layers and specific properties focused on a translation to 3D modeling and production programs. As indicated above, this process has also been followed and applied in the teaching on Urban Planning and heritage protection given by the authors at the Higher School of Architecture of Seville. In this way, both the case of the Plaza Nueva and its associated BIC (the City Council), and in the case of the convent of San Agustin, the students have generated a planimetry in AutoDesk AutoCad (using the versions of 2017, 2018, 2019, depending on the agreements and licenses of the University of Seville), which has served as the basis for an analysis of the current state of the surroundings. Similarly, the research work and professional assignments developed by the group and set out in this article have also followed the same methodology.

\subsection{Transposition to 3D modelling and postproduction of images and infographics}

Once the corresponding material has been produced using CAD technology, it is exported to other 3D modeling programs. In the cases presented, Rhinoceros $3 \mathrm{D}$ was chosen. This medium is a software tool for $3 \mathrm{D}$ modeling based on NURBS. It is a computer-aided design software created by Robert McNeel \& Associates, originally as an add-on for Autodesk's AutoCAD, becoming a tandem that allows the production of didactic material with very wide graphic possibilities. (Xavier et. al., 2018). The versions used have been, as in the previous stage, those available with free license, varying between 4.0 and 5.0.

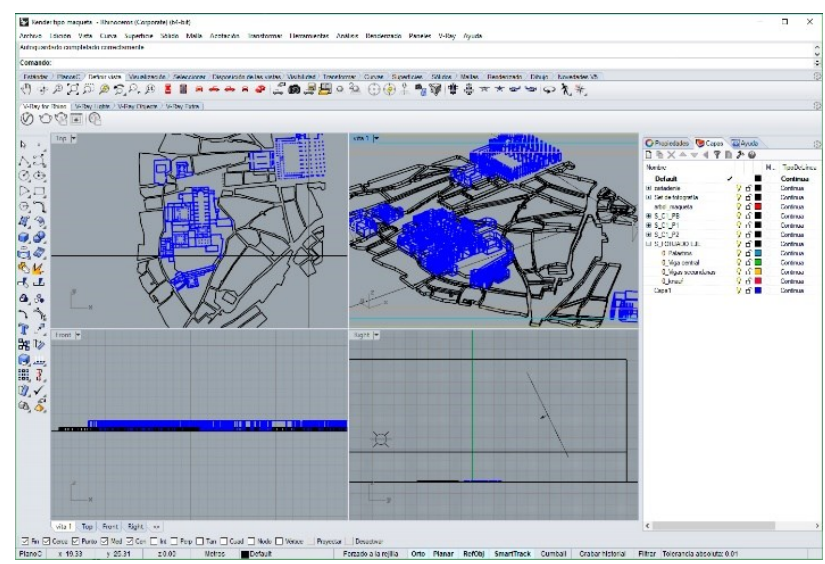

Figure 3. Rhinoceros 5.0 screenshot with 3D modeling prior to rendering (The authors, 2017)

For all the images we have worked with model language, without looking for a realistic image of the environments. The heights of the buildings or the dimension of the voids were the elements that were sought to represent. In order to do this, we have opted to work with a model-type language, simplified in unsubstantial textures and additions. It has been especially important to create a suitable work space, based on a sunny spot and a radiant screen, in what could resemble a photography set.

The implementation of a rendering engine such as V-Ray, developed by the Chaos Group company, which has allowed the simulation of model materials, has been fundamental and has confirmed the wide range of this engine in the production and architectural ideation (Velandia, 2011). The application of this technique has brought to light images that had never been possible before, such as the 3D appearance of the neighborhoodparish of Santa Maria around 1600 as a historiographic support to the evolution of the environment of the Plaza Nueva. Likewise, it has allowed to detail graphically the historical sequence of the Royal Shipyards and their multiple transformations. In the case where it has been most relevant has been in San Agustin, where a project to rehabilitate it in a hotel had been blocked on the grounds that the proposed height exceeded the height of the old church: thanks to metric studies of engravings and historical views it was possible to build the $3 \mathrm{D}$ image of the eighteenth century. 


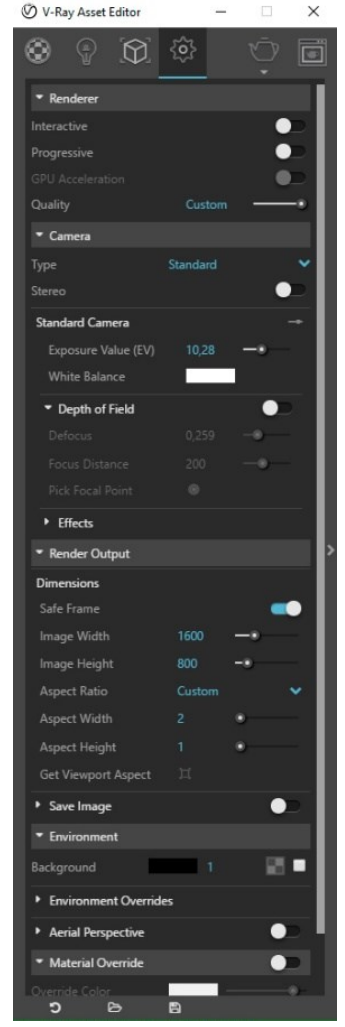

Figure 4. Screenshot of the V-Ray configuration used to produce the images of the Plaza Nueva (The authors, 2017)

\section{PLAZA NUEVA: THE RECONSTRUCTION OF A VACUUM}

The decree of opening new public spaces issued by José Bonaparte in 1810 is the germ of the conversion of conventual structures into public spaces in the city of Seville (Piqueres, 2012). The state of conservation of these architectures, which had been the functional muscle of the capital of the Golden Age, was already weakened by the French occupation itself and the decrease in the number of clerics, a prelude to the disentailments that would follow throughout the 19th century. This strategy of transforming the fabric would be executed in three paradigmatic cases: the convent of Santa Cruz, the convent of the Encarnación and the convent of San Francisco (Ollero, 2015). While the first of the resulting spaces mimics the fabric of the Santa Cruz neighbourhood, the convent of La Encarnación will give rise to a market of supplies of which a city suffered since the replacement of the Casa Lonja by the Archivo de Indias (Archive of the Indies).

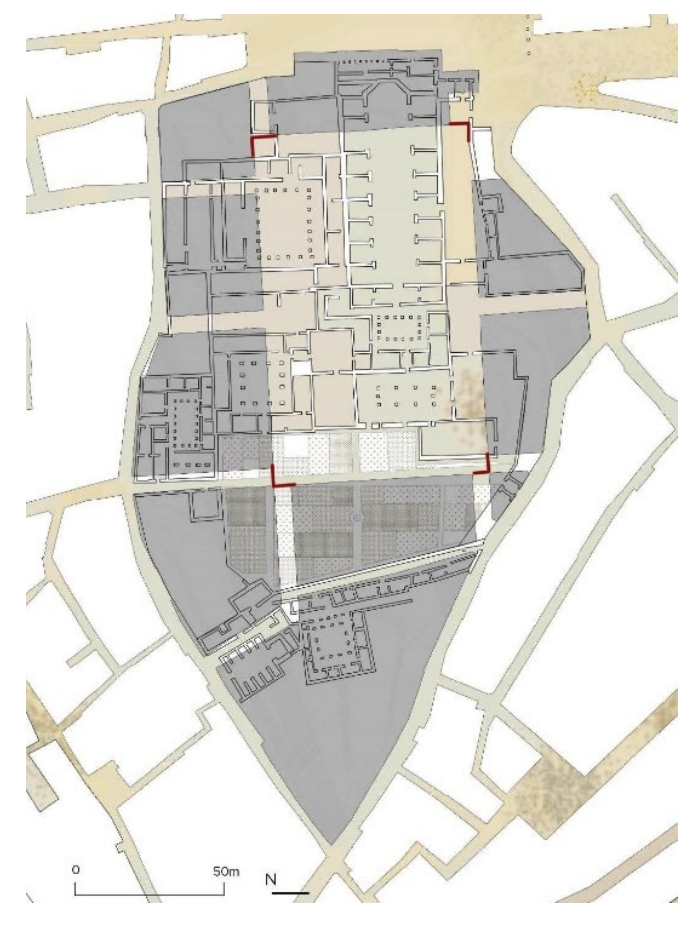

Figure 5. Superposition of the blocks that make up the perimeter of the square and the convent floor: a millimetric

correspondence arises between the shape of the complex and the line of rear facades. The future perimeter of the square is framed in red. (The authors, 2019)

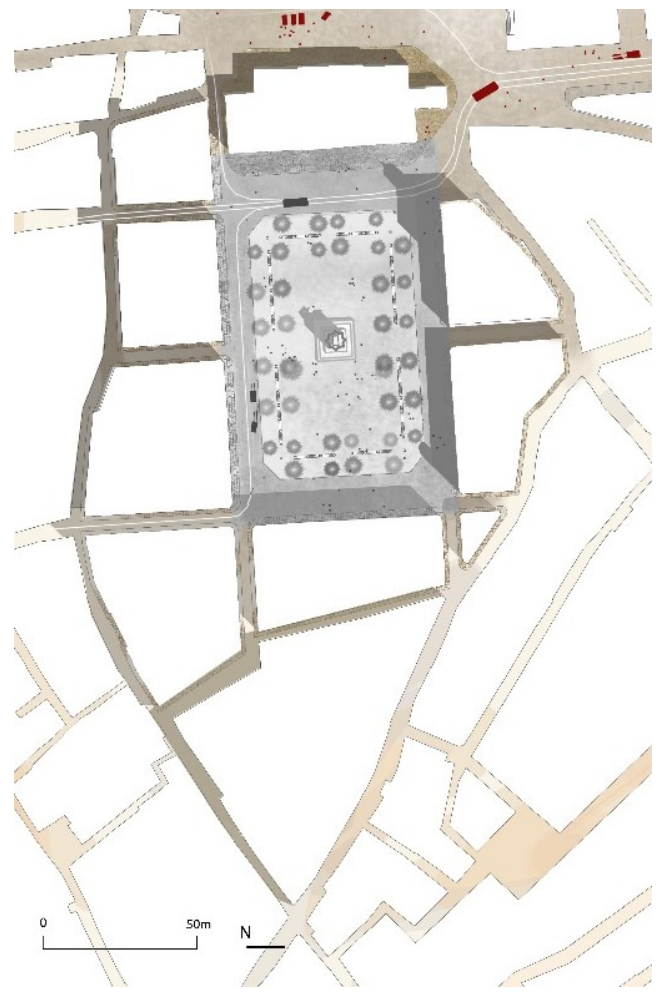

Figure 6. The square around 1930, with the silhouette of the two volumes grafted in the south sector visible through its shadow. The elimination of two thirds of the marble and wrought iron seats stands out in a strategy of dismantling urban furniture.

(The authors, 2019) 
The last of the extinct convents would be succeeded by a square of orthogonal geometry - presided over by the civil power represented in the Town Halls - which would end up capitalising on the nineteenth-century bourgeois emulsion and the definition of the space-symbol of a new Seville. Cayetano Vélez and Ángel de Ayala, consecutive municipal architects, will unsuccessfully design two projects without ever materialising, either because of a lack of resources during the French presence or because of internal discrepancies between the promoters in charge of their execution (Garmendia, 2015). The definitive project, executed in 1856 by Balbino Marrón, would provide a suggestive radical matrix, capable of executing the symbolic exchange between ecclesiastical power - defined in the definitive demolition of the convent, of which only the town halls attached to its head and a side chapel will be maintained - and the res publica civitas. The Plaza Nueva in Seville thus introduces the novelty of an open space, completely unusual in a context that is still alien to alignments, openings and expansions in which the Islamic fabric continues to found the logic of weaving.

\section{THE CONVENT OF SAN AGUSTIN: HEIGHT AS LIMIT PARAMETER}

The Convent of San Agustin (St. Augustine) in Seville was the first male construction of the Augustinian Order in the city. Its foundation dates from 1249, although it was in 1992 when the order moved to this location, beyond the city walls and next to Puerta de Carmona, one of the historic city gates of Seville. Like other buildings of this nature, the construction was progressive, ranging from the thirteenth century to the eighteenth century. However, it would be around 1612 when it acquired a configuration close to the definitive one. This one would be similar to that of other male convents outside the city walls. The compass, the three-nave church, the main cloister, the second cloister for novices, other smaller courtyards, the refectory and the Profundis hall were on the ground floor. On the second floor, the library over the refectory and the bedrooms and individual cells in the east would be located.

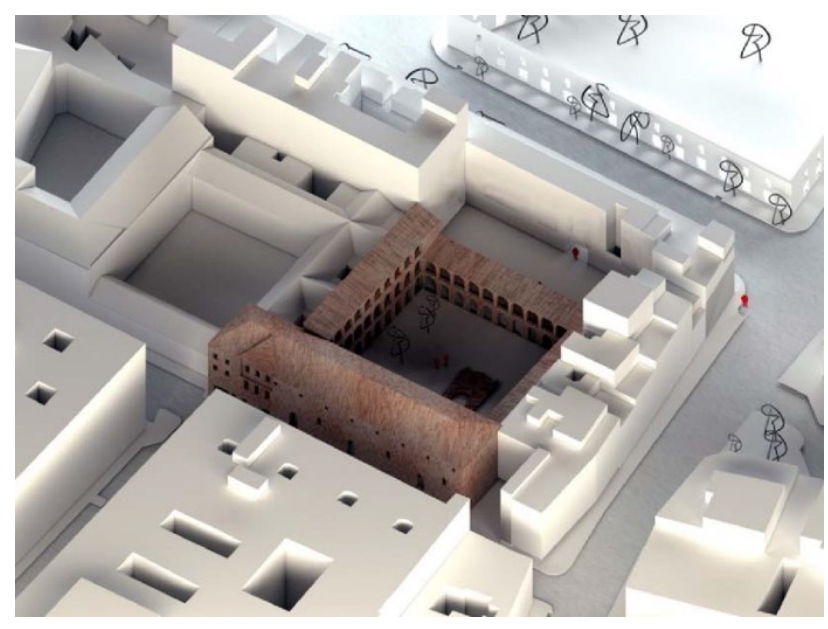

Figure 8 . Volumetry of the convent's pre-existence in their current status (The authors, 2018)

The convent was cloistered in 1835. Since then, it has taken on various uses, such as a prison during the French occupation, a provisional market for daily supplies, a military quarter, a forge or a garage. The needed typological adaption to these new uses has ended up blurring the conventual limits. In addition to an incomplete understanding of the whole complex, this fact has led to the loss of some of its rooms. As a consequence, the convent was classed as a monument in 1964, including only the refectory and the cloister (Perez-Cano, 1997); in fact, only some of these spaces characterised by high heritages value are preserved at present.

Among the pre-existence, we highlight the refectory, which is recognised as one of the most impressive Gothic spaces in Seville (Martínez-de-Aguirre, 1992). It is a large rectangular hall (41 m long, $9 \mathrm{~m}$ wide and $8 \mathrm{~m}$ high) covered by ribbed vaults that date from the early fifteenth century, even before the construction of the cathedral. The Mannerist cloister is equally remarkable. It is made up of two levels on the south and west sides, while the north and east incorporate an additional floor. Characterised by having a square floor plan (33 meters on each side), it was built mainly in brick, except for the double Tuscan marble columns on which the galleries 4 meters wide on the first-floor rest. On its northeast side, the monumental staircase that connected with the first floor is preserved. The opening of windows in the upper part was able to illuminate this space.

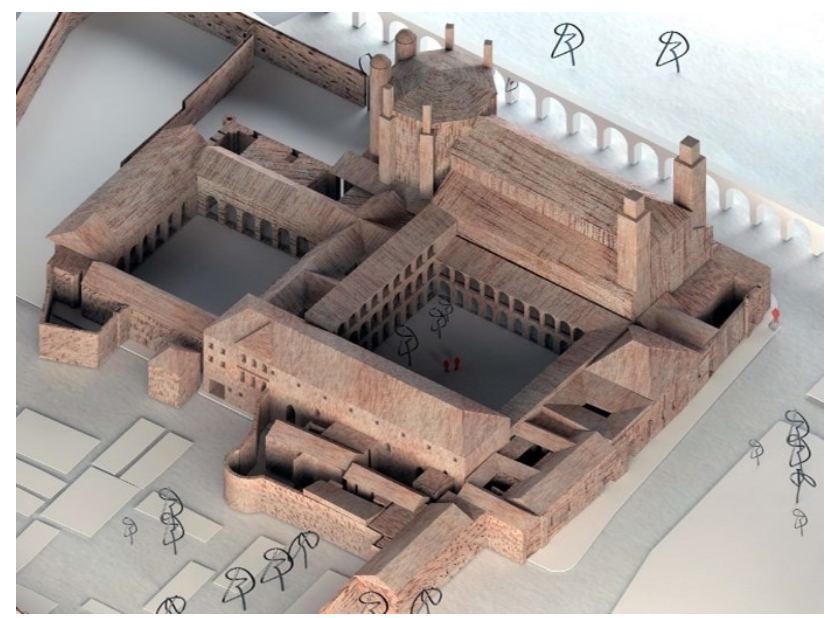

Figure 9. Hypothetical volumetry of the convent based on historic engravings, plans and drawings. (The authors, 2018)

The research carried out about this building is linked to the preliminary studies that are necessary for any heritage intervention. Specifically, the work has focused on establishing a hypothesis on the volume reached by some of the conventual units that were demolished. Among the most recent losses, we can point out the novitiate cloister, which would be located in the current central courtyard of the adjacent block of flats. Although with smaller dimensions, it would be formed by two bodies that would follow the same system of semi-circular arches on marble columns used in the main cloister. Among the outbuildings that have disappeared, the church stands out, whose particular symbolic value, inside and outside the religious ensemble, will also be reflected in the height that its central nave could reach. Thus, this case is different from other disentailed conventual complexes in this and other cities, where the church is usually one of the dependencies conserved having maintained as a sacred place of worship for decades.

The working hypothesis is based, among other documents, on a 19th-century-floor plan that was found in the General Archive of the Administration in Alcala de Henares (Fernández-González, 2013). This document gives us a clear idea of the distribution of 
uses, although there is no reliable documentation that would allow us to make an exhaustive volumetric survey of this ensemble. In this circumstance, the virtual representation in 3D is seen as an ideal tool to compare the volumetric hypothesis with the existing historical images of the surroundings of the convent. For example, through Richard Ford's engravings, it is possible to establish dimensional relationships between the church of the convent and the nearby Roman aqueduct (Caños de Carmona) and the historic city gate.

This volumetric verification can also be carried out by comparison with other conventual ensembles of the city that present similar characteristics and whose churches are still preserved, such as San Pablo el Real (1248) or La Trinidad (1249). Both are male monasteries whose construction was contemporary and dimensions, both of the whole ensemble and the church, were similar. It is known that religious buildings, like many other historical uses, followed typological models based on the dimensional relationships between floor plan and section. These relationships were mainly derived from construction systems that had been tested for centuries.

\section{REALES ATARAZANAS: AN OPEN CONSTRUCTION OVERTIME}

This building was ordered to be built by Alfonso X in 1252. The Reales Atarazanas was going to have an essential use as shipyards and galleys producer, reason why its location had to be significant, as well as facilitating the entry and exit of the ships. Although supported on the city wall, it was built in its outer side. The place chosen was the zone known as Arenal, since the difference in height in comparison to the river barely reached one meter, allowing the building to have an open façade for direct access of boats.

The shipyards were designed as ample diaphanous space, structured through a concatenation of arches supported by rectangular section pilasters made of brick that save a span of eight meters. These generate a sequence of two-side roofed naves placed perpendicularly to the river, and whose dimensions are one hundred meters long and twelve meters high (BarrionuevoFerrer, 2005). The arches are established in two directions, perpendicular to each other, thus producing a visually transparent space with an impressive double perspective. The interior is currently made up of seventeen naves and is expected to be refurbished as a cultural centre in the next few years.

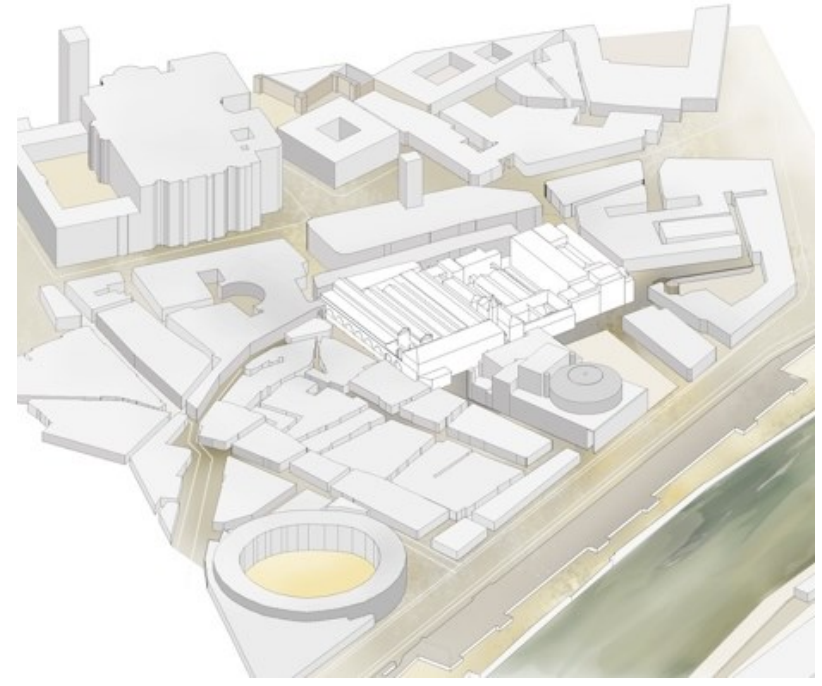

Figure 6. Volumetry of the shipyards' pre-existence in their current status (The authors, 2017)

The great diaphanous spatiality achieved thanks to the aforementioned formal resolution has conferred on it the capacity to admit a wide variety of uses throughout its history (PérezMallaina, 2012; Fernández-Rojas, 2013). When it was founded, three naves were enlarged on its northern flank. However, it was not until the 16th century that changes in use led to significant changes in its morphology. The first alteration comes from the end of the activity as shipyards to locate in the first nave the fish market that had been located in the Plaza de San Francisco until that moment. In addition to the compartmentalization of the space to locate the different sales stands, works were carried out for the construction of housing.

Thanks to, among others, the archaeological works of QuirósEsteban and Amores-Carredano (1997), it is known that these modifications also involved raising the level of the naves by almost four meters. It should be noted that the Arenal, turned into a port area, had raised its height as a defence system, so the shipyards had to perform the same operation to prevent flooding. At the end of this century, three of its naves were adapted to locate the Customs, and two additional naves were built to store wool and straw. This intervention respected the space system, offering a clear understanding of the general system. 

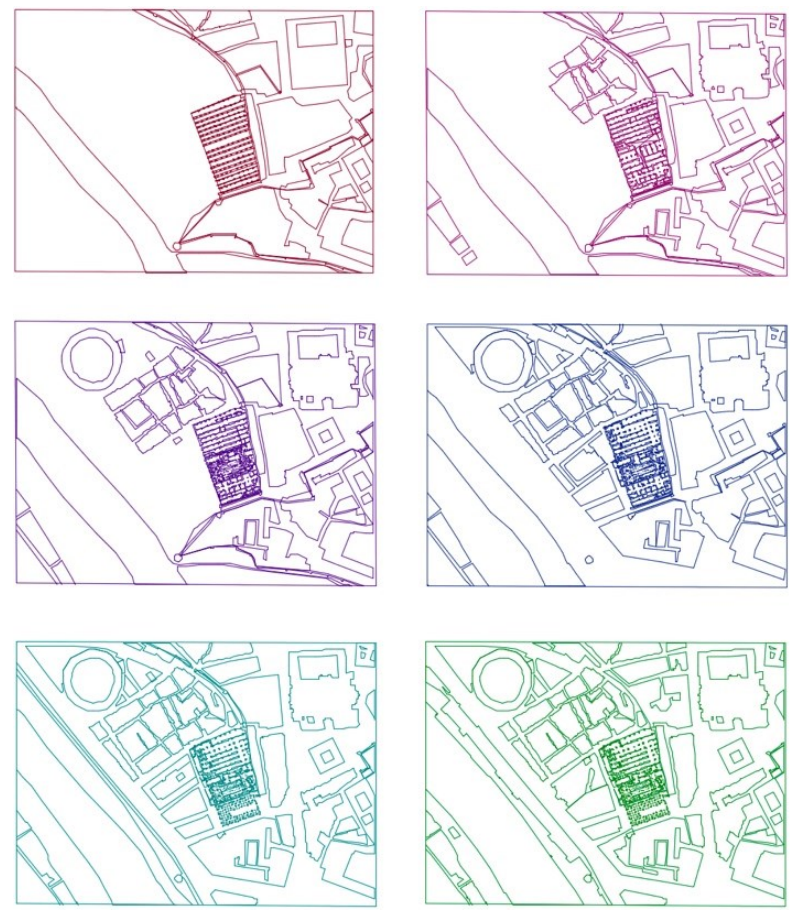

Figure 7. Screenshot of the 2D drawings made for the historical evolution of the shipyards and its surrounding: $13^{\text {th }}, 16^{\text {th }}, 17^{\text {th }}-$ $18^{\text {th }}, 19^{\text {th }}$ and $20^{\text {th }}$ centuries. (The authors, 2017)

By the mid-17th century, five of the naves were transformed to house a hospital. Although their physiognomy was highly modified, the interior spaces of the Hospital de la Santa Caridad were marked by the directionality and imprint of the structure of the primitive naves. In the 18th century, the consolidation of the apple happened, due to the reforms introduced by the Real Maestranza de Artillería. Three galleries are built perpendicular to the seven naves of the shipyards. A room for the weapons depot was also raised and the complex was endowed with a common volume that introduced the entrance into the centre of the ensemble. In the 19th century, the main modifications were exterior, with the creation of the Pasaje Temprado, a passage next to the entrance gardens. Towards the middle of the 20th century, the last significant intervention took place. The five naves of the southern zone were demolished for the construction of the Provincial Delegation of the Spanish Tax Agency.

This flexibility has even favoured significant modifications such as the adhesion or subtraction of naves. In this sense, we think that the principal value of this building lies in having been conceived as a system that allows progressive adaptation to the needs arising. Therefore, the Reales Atarazanas is presented as an enormous historic container of many uses and is an appropriate case in which to use 3D modelling tools to virtually represent the internal variability, but also its surroundings changes, experienced throughout its history.

\section{IMPLICATIONS OF 3D APPLICATION IN BIC ENVIRONMENTS}

The choice of the three cases presented has been based on the difference of scales, as well as on the type of data and details needed within the assessment. This has determined not only the bibliographic and graphic historical sources of information, but also the tools used for processing and post-production of the resulting images. While plain projections with shadows cast were selected as a final result in the case of Plaza Nueva (L scale), but a linear 3D model was needed when incorporating the volume of the precedent convent and buildings. The same happened with shipyards' pre-existence ( $\mathrm{M}$ scale), where in addition to the $2 \mathrm{D}$ drawings, made for the historical evolution, height of the building and ground level turned to be one of the main issues of the heritage debate. A similar need was detected in the Convent of San Agustín (S scale), where testing the hypothesis on the volume reached by some of the demolished conventual units, based on historical plans and engravings, was considered a key factor for the height determinations of new buildings.

Once the 3D modelling tools have been applied to three different case studies of BIC assets in the historic centre of Seville (Spain), with a particular attention to their built environments, we can highlight the relevance and usefulness of these tools when determining and assessing values related with the historical development, occupation and transformations of the area. Furthermore, they have been revealed as especially helpful when determining the impact in terms of volume, perspectives, buildability or height conditions in historic building and areas declared as Asset of Cultural Interest (BIC) according to Andalusian legislation, which barely can be understood and transmitted by the use of the traditional 2D plans and sections. In all cases, post-production labours have been relevant for an effective graphic communication.

The use of $3 \mathrm{~d}$ modelling and post-production added to the construction of a previous 2D planimetry has permitted a full recognition of the BIC environments: from a general location of the assets in the urban area to an in-depth analysis of the built context. Thus, both a metric-scientific definition of the spatial parameters of the buildings and an easily understandable spreading of urban heritage are possible by the use of a single combination of tools that provides a strong graphic potential. Furthermore, they permit the improvement of the knowledge of urban and architectonic evolution, as well as their use as teaching material.

In conclusion, the results obtained demonstrate the consolidation of 3D modelling and post-production tools as a useful combination for assessing the possible effects of interventions in BIC assets considering their environment. Furthermore, they offer an added possibility, not explored on this paper, of generating human-scale perspectives by introducing cameras inside the structures under study. Finally, their usefulness has been demonstrated by the use of visual documentation in several technical reports that have managed to unblock lengthy disputes between heritage organisations and various public promoters.

\section{ACKNOWLEDGEMENTS}

This paper has been developed under the project entitled "Caracterización Urbano Patrimonial y Modelo Turístico Cultural en Ciudades Medias. Potencialidades y Retos para su Internacionalización: Bética Interior" (HAR2016-79788-P), financed by the competitive call of the State Plan 2013-2016 Excellence - R\&D Projects of the Ministry of Economy and Competitiveness of the Government of Spain. 


\section{REFERENCES}

Barrionuevo-Ferrer, A., Molino-Barrero, J., 2005. Las atarazanas de Sevilla: entre la construcción y la arquitectura. Informes de la Construcción, 57(497), pp. 128-184.

De-Carvajal, Á. I. M., 2008. La Ley del Patrimonio Histórico Andaluz 2007 y el Planeamiento Urbanístico. Erph_revista electrónica de patrimonio histórico, 3, pp. 3-28.

Fassi, F., Mandelli, A., Teruggi, S., Rechichi, F., Fiorillo, F., Achille, C., 2016. VR for cultural heritage. In: International Conference on Augmented Reality, Virtual Reality and Computer Graphics, Springer, Cham, pp. 139-157.

Fernández-González, A., 2013. El desaparecido monasterio sevillano de San Agustín planos inéditos del siglo XIX. Archivo español de arte, 344, pp. 311-330.

Fernández-Rojas. M., 2013. Las Reales Atarazanas de Sevilla. Arte Hispalense, Sevilla.

Fritsch, D., Klein, M., 2018. 3D preservation of buildingsreconstructing the past. Multimedia Tools and Applications, 77(7), pp. 9153-9170.

Garmendia, J. M. S., 2015. En torno a la arquitectura doméstica sevillana del siglo XIX: el paso del neoclasicismo a la arquitectura isabelina. Laboratorio de Arte: Revista del Departamento de Historia del Arte, 27, pp. 321-343.

Gobierno de España, 1985. Ley 16/1985, de 25 de junio, de Patrimonio Histórico Español. Boletín Oficial del Estado, 155, pp. 20.342-20.352.

Junta de Andalucía, 2007. Ley 14/2007, de 26 de noviembre, del Patrimonio Histórico de Andalucía. Boletín Oficial de la Junta de Andalucía, 248, pp. 6-27.

Martínez-de-Aguirre, J., 1992. El refectorio de San Agustín y la asimilación del Gótico en Sevilla, Archivo Hispalense. Revista histórica, literaria e histórica, 229, pp. 109-130.

Moreno, J.R., 1993. Ad marginem: la collación de Santa María la Mayor de Sevilla. [Doctoral thesis]. Universidad de Sevilla, Sevilla.

Navas-Carrillo, D; Del-Espino-Hidalgo, B; Navarro-de-Pablos J., Pérez-Cano, T., 2018. The Urban Heritage Characterization using 3D Geographic Information Systems. The System of Medium-Sized Cities in Andalusia. In: International Archives of the Photogrammetry, Remote Sensing and Spatial Information Sciences, Vol. XLII-4 (W10), pp. 127-134.

Ollero, F., 2015. Ciudad e Ilustración. Transformaciones urbanas en Sevilla, 1767-1823. Cuadernos dieciochistas, 16, pp. 215-257.

Quirós-Esteban, C. A., Amores-Carredano, F., 1997. Primera intervención arqueológica en las antiguas atarazanas de Sevilla. In: Anuario Arqueológico de Andalucía 1997, Consejería de Cultura de la Junta de Andalucía, Sevilla, pp. 564-573.

Pérez, J. C., Mora, R. T., Pérez, V. R., Piedecausa-García, B., 2017. From CAD to BIM: A New Way to Understand Architecture. WIT Transactions on The Built Environment, 169, pp. $45-54$.
Pérez-Cano, M.T., 1996. Patrimonio y Ciudad. el Sistema de los Conventos de Clausura en el Centro Histórico de Sevilla: Génesis, Diagnóstico y Propuesta de Intervención para su Recuperación Urbanística. SPUS, Sevilla.

Pérez-Mallaina, P. E., 2012. Las Reales Atarazanas de Sevilla, 1252-1493. Un astillero medieval en el extremo occidental de Europa. In: Descubridores de América. Colón, los marinos y los puertos. Sílex, Madrid.

Piqueres, A. J., 2012. José I, “El Rey Regenerador”. E1 discurso josefino sobre la regeneración de España. Cuadernos de Historia Moderna, 11, pp. 123-144.

Ruiz, J. C., 1995. Una aproximación a la definición teórica, material, jurídica y procedimental del entorno. PH: Boletín del Instituto Andaluz del Patrimonio Histórico, 3(10), pp. 34-37.

Velandia, D., 2011. Modelado digital y diseño paramétrico como opción en la experimentación, desarrollo, visualización y toma de decisiones para estudiantes de arquitectura: Experiencias en un curso electivo. In: XV Congreso SIGRADI 2011.

Verdú, M. A., López, Ó., Lozano, R. V., 2015. Estudio del desarrollo e implementación de las tecnologías BIM en las universidades españolas. In: COINVEDI. 3th International Conference on Construction and Building Research. Universidad Politécnica de Madrid, Madrid.

Xavier, J. P., Sousa, J. P., Castro, A., 2018. Didactic Experiences on Digital Modeling. Anamorphosis. In: International Conference on Geometry and Graphics, Springer, Cham, pp. $1789-1800$. 